\title{
SECRETARIAT FOR RED CRESCENT AND RED CROSS SOCIETIES IN ARAB COUNTRIES
}

In its March 1975 issue, International Review gave an account of the Seventh Regional Meeting of Arab Red Crescent and Red Cross Societies, held in Riyadh last January. It mentioned that among the items on the agenda was the question of the establishment of a permanent secretariat for those National Societies. Panorama, the League's publication, gives further details in its latest number (1975, No 2):

A regional secretariat serving Red Crescent and Red Cross Societies in Arab countries is to be set up in Jeddah, Saudi Arabia. The late King Faisal of Saudi Arabia, who was Patron and Honorary President of the Saudi Arabian Red Crescent, ordered funds to be provided for the establishment and running of the centre.

King Faisal's gift, which made possible the realization of a project which had been under study for several years, was announced at the VIIth Conference of Arab Red Crescent and Red Cross Societies. Seventy-five delegates from 18 National Societies and representatives of the League, the ICRC and the Study for the Re-appraisal of the Role of the Red Cross attended the meeting, held 27-31 January.

The Conference immediately selected Saudi Arabia's diplomatic capital as the site for the Secretariat, and named Mr Abdul Ghani Ashi, Vice-President of the Saudi Arabian Red Crescent, as its executive officer.

The Secretariat will co-ordinate the humanitarian work of Societies in Arab countries, with particular emphasis on assistance to new and developing Societies, and will strengthen co-operation with the League and the ICRC. A projected Arab institute for volunteer training may also eventually be attached to the Secretariat...

...Among other decisions, the Conference voted to allocate annually 36,000 Kuwaiti dinars to finance research work on war injuries, and asked for the co-operation of the ICRC and the League. 